higher than in pre-war years, the average egg consumption in $193 \mathrm{I}$ being estimated at I $58 \mathrm{eggs} /$ head (Reorganisation Commission for Eggs and Poultry, 1935). The egg consumption in 1946 was partly derived from imports and partly from home production. The amount derived from imports was 4623 million eggs and approx. 4000 millions were from home production. Since egg imports will be seriously curtailed owing to financial stringency, an extra home production of 6000 million eggs will be required if the amounts recommended for consumption are to be obtained. On the poor quality of feeding-stuffs at present available for poultry, the average annual egg production/hen does not exceed roo eggs. The extra number of hens needed to produce the eggs required would be 60 millions; this would be reduced to 43.3 millions if feeding-stuffs of pre-war quality became available, since under such conditions it should be possible to step up the average annual egg production to 120. Expanding the poultry population by this amount would present no major difficulty provided feeding-stuffs were available. The extra feeding-stuffs required must come from home production or from imports. Two possibilities of expanding home production are, first, release of home-produced barley and wheat for animal feeding, and secondly, reduction of the flour extraction rate, thus releasing extra supplies of wheat offals. It is estimated that release of an extra $10 \%$ of the wheat and barley crop for animal feeding would yield $363,950 \mathrm{t}$. of grain, and the reduction of the flour extraction rate from its present level to $70 \%$ would yield an extra $747,240 \mathrm{t}$. of wheat offals. Assuming that it takes $6 \mathrm{lb}$. of food to produce twelve eggs, that the average egg production/year is 120 eggs, and that it takes $20 \mathrm{lb}$. of food to rear a bird to the stage of laying, the extra feeding-stuffs available, if the courses I suggest are adopted, would suffice to produce 3733 million eggs. This would leave a gap of 2267 million eggs which could only be filled by the importation of feeding-stuffs. Calculated on the same basis as before, the amount of imported feeding-stuffs required would be $668,750 \mathrm{t}$. On the assumption that extra wheat and barley are released for animal feeding, and that the rate of extraction of flour is reduced to the pre-war level of $70 \%$, it should be possible to raise home production of eggs to a level of $16 \mathrm{r}$ eggs/head, on the assumption, of course, that the extra supplies of home-produced feeding-stuffs are used entirely for poultry feeding.

\title{
REFERENCES
}

Bransby, E. R., Magee, H. E., Bowley, M. C. \& Stanton, B. J. (I 947). Brit. F. Nutrit. I, 275. Reorganisation Commission for Eggs and Poultry (1935). Econ. Ser. Minist. Agric. no. 42.

\section{Summing up}

\section{By A. W. Ashby, Agricultural Economics Research Institute, Parks Road, Oxford}

When I first saw the outline of the programme for to-day's conference, I suggested that someone should provide a general statistical background of home production, total supplies, consumption and recent changes therein, which the individual authors might 
use for guidance. When I saw the papers my judgement on this point was confirmed. So perhaps the most useful summary and lesson of this conference is that it is necessary for authors of such papers to work together in the closest collaboration and to work with a competent statistician who has experience and a good working knowledge of the data to be dealt with, as well as sound knowledge of statistical method. I will illustrate the reasons for this statement later on. In the meantime I would like to carry this suggestion much further, saying that, at this juncture, when the nation is short of required powers of both production and purchasing, when broad and far-reaching policies have to be promulgated, when the nation's economic resources have to be used to the best effect if any modicum of welfare is to be secured, the nation needs the services of a body like the wartime Scientific Food Policy Committee. There should be a scientific body which would have access to all available information as to home and total supplies, general resources and needs, and would be free to make suggestions and recommendations on policies and co-ordination of policies.

Under existing circumstances the wisdom of 'Whitehall' is quite inadequate to the national need of information, knowledge and judgement. Under these circumstances there is grave danger in reliance on individual experts and advisers, however eminent and well informed they may be in their own individual spheres. Similarly, I reiterate, the successful operation of a conference like this, needs such a foundation of committee work as will ensure agreement on basic data and will also ensure co-ordination of at least a minimum of claims, suggestions or recommendations.

If we turn to the papers, we find that Magee and his collaborators (Bransby, Magee, Bowley \& Stanton, 1947) use the League of Nations standard for their estimates of requirements and a 'comfort' level for their dietaries. Presumably they knew of, and considered, the standards of the U.S.A. National Research Council and rejected them. When we get to Hammond's (1947) paper we find he has accepted and used the American standards in respect of animal protein. There is also obvious disagreement between Bransby $e t$ al. and Hammond as to the need or value of protein from animal sources. Fäilure of agreement on such a point must cause confusion in respect of agricultural policy.

Perhaps Magee and his collaborators were'wise when they lumped together meat, fish and eggs in their statements of pre-war consumption and recent and future needs. There is advantage in having a good broad umbrella in case of rain, and perhaps even more in case of driving hail.

Hammond, proceeding largely on the basis of presumed consumption in pre-war years, sets needs of meat at an average of about $146 \mathrm{lb}$. carcass weight/head/year. $\mathrm{He}$ sets pre-war home production at $65 \mathrm{lb}$./head/year. I am informed by the experts that most of the pre-war estimates of home production of meat were too high. If that be the case, then estimates of total consumption were also too high.

The recent report on Food Consumption Levels in United Kingdom (Ministry of Food, 1947) puts pre-war home production at ${ }_{13} \mathrm{I}^{\circ} 7 \mathrm{lb}$. carcass weight/head and at I09.6 lb. edible weight. While these figures are for quantities moving into civilian consumption there cannot have been enough non-civilian consumption to account for a difference of I $4 \mathrm{lb}$./head over the whole population. 
I believe that the figure for what Bransby $e t$ al. call 'edible animal protein'--meat, fish and eggs (their Table 5)-is obtained from these bases: meat 109.6; poultry, game, rabbits and fish 32.8 ; eggs $24.5 \mathrm{lb}$. $-\mathrm{r} 66.9 \mathrm{lb}$. pre-war consumption. So, while Bransby et al. accept the most recent official figure for meat, Hammond uses another and much higher.

On the other hand, if we turn to Halnan (1947) we find the surprising conclusion that consumption of eggs in 1946 was higher than that of pre-war. He quotes a pre-war estimate of $158 \mathrm{eggs} / \mathrm{head} /$ year or, say, $19.75 \mathrm{lb}$. But the Ministry of Food's (1947) report on Food Consumption Levels in United Kingdom gives a total shell-egg equivalent of $24.5 \mathrm{lb}$. for pre-war and $2 \mathrm{r} \cdot 2 \mathrm{lb}$. for 1946 . On the basis of eight shell eggs/lb. the comparison is:

$\begin{array}{lccl} & \text { Pre-war } & (1945) & \text { r946 } \\ \text { Halnan } & \text { I58 } & - & 180 \\ \text { Report } & 196 & (208.8) & 169.6\end{array}$

I suspect that the consensus of housewives would be with the Report rather than with Halnan in respect of 1946 .

When I turn to Kay's (1947) statistics of milk production, sale and use, I do not find any figure for use of whole milk in livestock production in the past, present or future, or any reference thereto. Moreover, he uses two terms, namely, 'production' and 'sale off farms' with the same connotation. 'Production' includes quantities fed to livestock. Further scrutiny of Kay's basis of estimate for the rate of possible increase in yield of milk/cow may lead to some qualification.

Regarding Jones's (1947) paper there are features of the yields of crops, and in particular of wheat, which require further consideration. Jones cannot be justified in taking the yields of control plots under experimental conditions, in the case of wheat, potatoes or sugar-beet, as guides to potential production on 300,000 farms, or the large number of individual farms concerned with each of these specific products. Nor is he justified in taking yields of wheat from any such small number as a score of farms and extending them to the whole country. The universal repetition of the efficiency of a few farmers, working under supervised conditions, as under a system of supervised farm or crop costing, is very unlikely. The time lag in the spread of technical efficiency amongst farmers is quite well known. While the recent lag may be reduced by advisory work and propaganda, and more by direction and control, some lag will still remain, and for the moment there is a minimum of direction or control. If we reduce the potato acreage far enough, restricting it to the most productive land, we may approach Jones's postulated average yield of to t./acre. On the other hand, as we extend the acreage of wheat we must in the long run push the crop out to less productive land. Jones indicates a standard attainable yield at $22.5 \mathrm{cwt}$./acre. At the best annual average yields recorded, namely 20.3 in 1938 and 20.2 in 1942 , we have not exceeded $91 \%$ of that figure. Moreover, if we are to place more reliance on home production, we have to look at ninimum yearly average figures as well as the maximum, or even the long-term, average. The estimates of Lawes and Gilbert (Lawes, I868; Lawes \& Gilbert, I880; see also Venn, I926; Vigor, 1928) of yields of wheat for the United Kingdom in bushels/acre show these variations: 


$\begin{array}{cccc} & \text { High } & \text { Low } & \text { Average } \\ 1852-61 & 34.7 & 20.9 & 27.1 \\ 1862-71 & 38.7 & 21.0 & 29.5 \\ 1872-81 & 30.0 & 15.5 & 24.4\end{array}$

Recent estimated yields have shown more stability and probably this is in accordance with the facts of the situation. For Great Britain these variations in cwt./acre are found:

\begin{tabular}{|c|c|c|c|c|}
\hline & & High & Low & Average \\
\hline $1924-33$ & $\left\{\begin{array}{l}\text { Yield } \\
\text { Index }\end{array}\right.$ & $\begin{array}{r}19^{.2} \\
109^{\circ} 1\end{array}$ & $\begin{array}{l}\text { I6.I } \\
91.5\end{array}$ & $\begin{array}{r}17 \cdot 6 \\
100 \cdot 0\end{array}$ \\
\hline $1934-38$ & $\left\{\begin{array}{l}\text { Yield } \\
\text { Index }\end{array}\right.$ & $\begin{array}{r}20.4 \\
110.9\end{array}$ & $\begin{array}{l}16 \cdot 4 \\
89 \cdot 1\end{array}$ & $\begin{array}{r}18.4 \\
100.0\end{array}$ \\
\hline $1939-44$ & $\left\{\begin{array}{l}\text { Yield } \\
\text { Index }\end{array}\right.$ & $\begin{array}{r}20.4 \\
107.4\end{array}$ & $\begin{array}{l}17 \cdot 8 \\
93 \cdot 7\end{array}$ & $\begin{array}{r}19.0 \\
1000\end{array}$ \\
\hline
\end{tabular}

As regards the rate of increase in yield over a period of time it should be said that until I9I I only bushel records are available, and the bushel must be converted into cwt. to obtain comparisons with the recent period. Consequently, any calculation of the rate of increase from the earlier to the later period will depend on the conversion rate:

$\begin{array}{ccccc}\begin{array}{c}\text { Conversion rate } \\ \text { (lb./bushel) }\end{array} & \overbrace{\text { Bushels }} & \text { cwt. } & \begin{array}{c}\text { 1987-93 } \\ \text { cwt. }\end{array} & \begin{array}{c}\text { Percentage } \\ \text { increase }\end{array} \\ 60 & 29 & 15.53 & 19{ }^{\circ} & 22.3 \\ 62 & 29 & 16.05 & 19{ }^{\circ} & 18.4 \\ 64 & 29 & 16.57 & 19.0 & 14.7\end{array}$

Again, whatever rates of conversion are used, the rate of increase in yield has not been steady or consistent. There is a series of marked high yields relative to the period shown in the 5-year moving averages centred on 1907, 1908 and 1909, and another centred on 1927. While there has been somewhat more marked consistency in yields since 1939, the harvest of 1947 will again show a low average.

Local variations in yields of wheat may also be important when extensions of acreage are under consideration. Here we may obtain some guidance from the estimates of county average yields. In the period $1929-38$, the latest for which the estimates are available, the positions were:

$\begin{array}{cc}\begin{array}{c}\text { Yields, I0-year } \\ \text { averages }\end{array} & \begin{array}{c}\text { Counties } \\ \text { (no.) }\end{array} \\ \text { (cwt./acre) } & 6 \\ \text { Under } 15 & 7 \\ 15-15.9 & 17 \\ 16-16.9 & \text { Average at about } \\ 17-17.9 & 17 \text { 1 } 17.3 \text { cwt. } \\ 18-18.9 & 9 \\ 19-19.9 & 2 \\ 20-20.9 & 1 \\ 21-21.9 & - \\ 22-22.9 & 1 \\ \text { Over } 23 & \text { I }\end{array}$

While there cannot be any doubt that there are potentialities of increasing yield/acre and total production of crops in this country, they need more scrutiny and consideration 
than has been given by Jones. In particular, the need of raw materials for increased production has to be taken into account. And when all the material conditions for increase exist, the psychological requirement of educating and stimulating all, or a great majority, of farmers to their use will be both essential and difficult.

Close consideration of these papers will reveal some other 'factual', i.e. statistical, anomalies. Hammond says 'steps at present being taken. . . should lengthen the life of the dairy cow in the herd from 2.5 to 3.5 years and so reduce the turnover from about $20 \%$ to about $10 \%$ '. If these 'milking lives' were those of fact, the 'turnover' on 2.5 years' life would be $40 \%$ and at 3.5 years about $28.5 \%$ a year. This estimate of 2.5 years in the pre-war period was of the milking period in one herd or under one ownership, and cows moved from one herd and ownership to another or more. Between I900 and 1938 there were not enough heifers for such a short total milking life as 2.5 years and a turnover of $40 \%$ a year. If the effective birth rate is taken at $90 \%$ and half the calves are females, there would be only 45 heifers originally available/100 cows, and, in fact, some were killed as calves and very large numbers and proportions of females went to slaughter between 2 and 3 years of age. In Wales, a typical rearing area, nearly half the cattle graded in 1934-7 under the subsidy scheme (steers, heifers and cow-heifers) were heifers and cow-heifers. So far as it can be computed on a national basis the average milking life of dairy cows never fell below 4 years and in some periods almost reached 5 years.

The most important points to consider in these four papers are those of practical character. Jones's suggestions as to increase in crop areas are largely self-compensating, a saving in area under potatoes transferred to sugar-beet and wheat. The suggestions or claims of Kay and Hammond for milk and meat production are, however, competitive, and even conflicting, in respect of pasturage, bulk fodder and concentrates; and those of Halnan for egg production are competitive and conflicting with milk and meat in respect of concentrates. All are competitive as regards labour. The claims for increases in home supplies for human consumption are: Kay, milk, $\mathrm{r} 5-25 \%$; Hammond, meat, $70 \%$; Halnan, eggs, $66 \%$. Kay and Hammond both want more and improved pasturage for production of their commodities. They have a common interest in improvement of pastures but competitive interests in their uses. While the nation, and indeed the world, is short of concentrates for animal feeding, it will be impossible to follow all these programmes.

Perhaps if we turn to wartime policy and experience we may find some guidance. When we have to feed the greatest possible number of human beings from a given area of land or with given amounts of resources, we begin to achieve our object by inducing them to take the greatest practical amounts in the direct vegetable forms. Beyond this we have to select the types of livestock to be used largely according to their relative efficiencies as converters of spare vegetable products, or those which human beings cannot assimilate, into human foodstuffs. On a rough approximation the milch cow as converter is two and a half times as efficient as the beef bullock, and three times as efficient as the lowland sheep. The pig is a relatively efficient converter of carbohydrates and the hen a relatively efficient converter of proteins, but both the pig and the hen are direct competitors with human beings for grain products. There 
are some qualifications of these positions in respect of use of materials unavailable to man; as far as the beef and mutton animals in particular, and pigs to a lesser extent, can be used as scavengers, i.e. be fed on by- or waste-products, there will be economy in feeding small amounts of concentrates to ensure combinations for economical use of the available bulk feeds.

When the last war began, we set out to increase production of grain, potatoes and other vegetables, to maintain or increase production of milk and its sale off farms; to decrease lowland sheep production, and to decrease that of pig meat and eggs. We achieved the objects, largely those of increasing production and availability of calories and of increasing milk supplies. We reduced total home supplies of meat and eggs.

If we consider the suggestions of the papers by Kay, Hammond and Halnan regarding need of increases in home production against the targets set in the recent announcement of agricultural policy, we find the targets moving in the same directions as the suggestions in these papers in respect of livestock and grain, but in opposite directions for potatoes and sugar-beet. However, if we consider with the targets the relative prices for commodities announced or promised, we shall find that there has been little change in practical policy.

Prices fixed for wheat, barley and potatoes are relatively favourable. Amongst livestock products milk is given marked priority for the near future; and in the longer future milk is still given priority over beef. Improvement in the position of pig meat and eggs is promised for the near future but the price relative is still in favour of milk. And, generally speaking, farmers will frame policies in closer relation to prices than to targets. It is quite clear that determinations of requirements in food supplies will always be subject to economic, as well as to nutritional, considerations. The chief present need is a large increase in the productivity and income of the nation as a whole.

\section{REFERENCES}

Bransby, E. R., Magee, H. E., Bowley, M. C. \& Stanton, B. R. (1947). Brit. F. Nutrit. 1, 275.

Halnan, E. T. (1947). Brit. F. Nutrit. I, 299.

Hammond, J. (1947). Brit. $\mathcal{F}$. Nutrit. I, 292.

Jones, E. T. (1947). Brit. F. Nutrit. 1, 283.

Kay, H. D. (1947). Brit. F. Nutrit. I, 287.

Lawes, J. B. (1868). F. R. statist. Soc. 31, 339.

Lawes, J. B. \& Gilbert, J. H. (1880). F. R. statist. Soc. 43, $3^{\mathrm{I}} 3$.

Ministry of Food (1947). Food Consumption Levels in United Kingdom [Cmd. 7203]. London: H.M. Stationery Office.

Venn, J. A. (1926). Econ. F. 36, 394.

Vigor, H. D. (1928). F. R. statist. Soc. 9r, ז. 